\title{
The Strong Presence of Chinese Investment in Madagascar: Threat or Opportunity?
}

\author{
Miora Andriamampiandra, Mamy Hary Jean Andriamitsiriony, Jean Claude Razaranaina
}

University of Fianarantsoa, Fianarantsoa, Madagascar

Email: fontainerafamant@yahoo.fr

How to cite this paper: Andriamampiandra, M., Andriamitsiriony, M. H. J., \& Razaranaina, J. C. (2021). The Strong Presence of Chinese Investment in Madagascar: Threat or Opportunity? Modern Economy, 12, 919-928. https://doi.org/10.4236/me.2021.125046

Received: March 9, 2021

Accepted: May 7, 2021

Published: May 10, 2021

\section{Copyright (C) 2021 by author(s) and} Scientific Research Publishing Inc. This work is licensed under the Creative Commons Attribution International License (CC BY 4.0).

http://creativecommons.org/licenses/by/4.0/

\begin{abstract}
The purpose of this paper aims at giving an answer of whether the strong presence of Chinese investment in Madagascar is a threat or opportunity? In this regard, using the panel data over the period of late-1990s, which is marked by a significant influx of Chinese migrants until 2019, it is found that in one hand, the Republic of Madagascar wishes to attract investors and make the private sector the main engine for its development, the government adopted laws whose goal is to provide attractive and practical climate. It is also important to be able to deal with international competition and to build a tangible competitive advantage. In another hand, the reality is different from which was expected. Actually, the impact in the Malagasy's economy deceitful and the confidence between the two parties has been undermined. Many Chinese companies do not respect environmental conditions nor labor law. That is why the growing presence of Chinese investors creates dispute between the Malagasy government and the citizens.
\end{abstract}

\section{Keywords}

Chinese Investment in Madagascar, Investment Agreement, Foreign Direct Investment (FDI)

\section{Introduction}

The phenomenon of the internationalization of the economy has become irreversible those last decades. There are many reasons that can explain this situation: not only this process is an opportunity for each country to access the investment market all over the world, but also it is one of the solutions of the unavoidable interdependence between countries. Some countries have available funds and are willing to invest where conditions are pleasant. 
Madagascar is one of many countries that have undertaken many actions to guarantee investment and by the same time create a secured and attractive climate. There are also different measures that have been taken in order to attract many investors from different countries like adopting some permissive laws. For instance, there is no law prohibiting or limiting foreign investment in the country. Furthermore, the Malagasy government decided to set many reforms which aims at improving business climate and attract new investors. Let us recall until now Madagascar does not attract many major investors because of our political issues.

Like most of countries in Africa, Madagascar has chosen the implementation of its liberal economy policy with a different focus on opening up to the outside market.

Considered as one of the poorest countries in the world, Madagascar was often ignored since it is not powerful politically. At the same time, Madagascar has been through many political and economic crises since its independence. This is by the way, one of the reasons why not only some western actors left the countries without getting back anymore in 2009 and also the lack of savings has become the principal characteristic of the Malagasy economy. According to a report published by the World Bank, Madagascar still ranked 161st out of 190 economies (Doing Business Report, 2020).

Nevertheless, even some western investors left the country in 2009, Chinese investors reinforce their engagements. Madagascar and China have more than 40 years' relationship behind them. Actually, even the first Chinese migrant came in Madagascar in 1862, the diplomacy and economic relationship came up later.

China is one those rare countries that recognize the existence of a great potential for investment cooperation with Madagascar. In theory, foreign investment should be an important lever in a country's economy, but Chinese investments have been linked to a host of human rights violations in the country, ranging from child labor in mica mining to the illicit trade in precious rosewood. Malagasy government also considers Chinese investment as beneficial in many ways. First, China government does not care about the respect of the democracy and doesn't interfere in their political choices. Second, Chinese investment didn't step up in China despite of the crisis in Madagascar. That's why the economic and political ties between China and Madagascar have become significantly tighter in recent years. Actually, since 2005, the Sino-Malagasy's relationship evolved into an investment relationship. The stock of FDI from China to Madagascar raised. Let's recall that FDI stands for "Foreign Direct Investment". In other words, it is the capital inflow of foreign investors (Carreau \& Julliard, 2013) that help host state to strengthen infrastructure, increase their productivity and create employment opportunities.

According to UNCTAD's World Investment Report $2020^{1}$, the country re${ }^{1}$ United Nations Conference on Trade and Development is established to promote development among the so-called "un-developed" and "under-developed" newly independent countries. Its purpose was to facilitate the integration of these economies into the world economy through a balanced approach. 
ceived USD 227 million in Foreign Direct Investment (FDI) inflows in 2019, a decrease compared to USD 353 million in 2018. The stock of FDI has been rising and reached USD 7.7 billion in 2019.

Investing in Madagascar is also a natural choice for Chinese investors since it has enormous natural and various potential. However, Malagasy people doubt about the fact that foreign investment can be useful the country development. The local communities do not understand why the government let foreign companies to use their lands. The government and the local communities do not agree about this situation. The first one see the opportunity to get richer, most of Malagasy people see their wealth fade away.

\section{Background}

\subsection{Background of China and Madagascar Relationship}

The first Chinese migrant arrived in Madagascar between 1896 and 1901 (Bardonnet, 1964). At the very beginning, they were only meant to help to build the railway in the East cost of Madagascar. Later, they were given the name "les coolies" and built families with Malagasy women. The conditions of access of Asians to Madagascar were regulated by the provisions of a decree dating from 1932, which governs all French colonies by setting strict controls for the entry of non-European immigrants into the territories. But despite the existence of this decree, from 1920 until 1939, the flow intensified. From 1937 when 573 Chinese landed in the port of Tamatave, followed by 450 immigrants in 1938 (Donque, 1968) (Table 1).

Table 1. Evolution of the number of Chinese in Madagascar.

\begin{tabular}{cccc}
\hline Year & $\begin{array}{c}\text { Number of Chinese People } \\
\text { living in Madagascar }\end{array}$ & Year & $\begin{array}{c}\text { Number of Chinese People } \\
\text { living in Madagascar }\end{array}$ \\
\hline 1896 & 50 & 1961 & 8900 \\
1904 & 452 & 1967 & 9203 \\
1909 & 512 & 1972 & 10,000 \\
1921 & 935 & 1996 & 16,000 \\
1931 & 1805 & 2001 & 20,000 \\
1939 & 3372 & 2005 & $20,000-50,000$ \\
1941 & 3637 & 2007 & $40,000-60,000$ \\
1951 & 4900 & 2009 & 60,000 \\
1958 & 8039 & 2011 & $70,000-100,000$ \\
\hline
\end{tabular}

Source: INSTATT, 2014.

According to the INSTATT, which is an institute that aims at carrying out any research on the national economy and produces national statistics, the number of Chinese people living in Madagascar grows fast from 2005 until 2011. (INSTATT's Report, 2012). 
The majority of the Chinese migrant were rather a community of traders (LMS SLAWECKI, 1964), today there is a mass of investors who are settling in. The relationship between the two countries has therefore gone beyond the simple diplomatic framework (PELLERIN, 2011) and has evolved into an economic relationship. Therefore, an agreement was signed between the two countries on November 05, 2005. It is the investment promotion and protection agreement between the People's Republic of China and the Republic of Madagascar which main objectives are to facilitate the establishment of companies and the transaction of capital. The investment agreement between the two countries promoted the establishment of Chinese company in Madagascar.

\subsection{Background of China's FDI in Madagascar}

Madagascar is on the 10th position in Africa among countries that have recorded the highest FDI in 2007-4th position in Sub-Saharan Africa-behind Tunisia. Within the East African and Indian Ocean Islands region, Madagascar is now the foremost FDI recipient country (Afrobarometer, 2009).

In 2011, there were 56 Chinese investment companies in Madagascar. The mining sector is dominating in terms of FDI stock because Madagascar boasts a rich array of valuable minerals, including iron, manganese, and copper. In 2015, the statistic of EDBM (2013) demonstrates that the number of the investment companies has grown consequently. Actually, there were 168 Chinese firms.

\begin{tabular}{cc}
\hline Investment Sector & Number of Chinese companies \\
\hline Mining & 32 \\
Industry & 12 \\
Energy & 6 \\
Agriculture & 5 \\
Tourism & 1 \\
\hline
\end{tabular}

Source: Source: Edbm/Authors calculations.

In 2011, there were 56 out of 210 companies which were legally incorporated. In other words, 156 were in illegal situation. Even though, some of the $56 \mathrm{com}$ panies already had their operating license, some didn't. The fact is, even if some of them did not have their mining permit, they still act like they did and keep operating everywhere. Needless to recall that only prospectors and miners who fulfilled the process of environment, land and commune approvals are granted by the respective departments and can commence their activities. The publishing of a decision and also a verification of administrative fees are also needed. However, there were firms which were forced out because of their illegal behavior. It is the case of the Mainland mining company in 2011. Mainland mining was one of the first Chinese companies which were settled in Manakara Madagascar. Actually, they did not respect important environment obligations. 


\subsection{Government's Measures to Motivate FDI in Madagascar}

The goal of the government is trying to make the country a more attractive destination for FDI, through several initiatives and incentives. For example, there are many companies active in the renewable energy, tourism, industrial, and construction sectors can benefit from a tax reduction equal to the tax calculated on $50 \%$ of the amount of investment that they realized during the related tax year.

To facilitate the settlement of all those companies, the Malagasy government created the Economic Development Board of Madagascar. It is an investment promotion company. It is also responsible for the formulation of appropriate investment promotion policies and strategies. The EDBM's role is to ensure that the business climate of Madagascar is attractive and conducive for the success of private enterprises and for investments in general.

Therefore, strategies are:

- the establishment a competitive business environment,

- security of investments and trade,

- intensive promotion of Madagascar to attract

Since the government want to provide a climate which is practical, attractive, transparent and avant-garde for all investment activities in Madagascar. They have adopted many laws that aims to adapt and boost rapidly the local economic fabric so that it converges into an international economic context which is particularly competitive.

As far as petroleum code is concerned, it provides a custom and importation duties exemption for hydrocarbon research, exploration, and exploitation activities. A mining company committing to invest more than USD 50 million can benefit from a minimum income tax exemption, a reduced corporate income tax rate for the transformation entity, exemption from custom and importation duties.

Furthermore, the law $\mathrm{N}^{\circ} 2007-036$ allows foreign investors to proceed by a long-term lease and use a property without being its owner. The long-term lease locks in the price the investor pays for asset, which is advantageous because prices often upward. For the case of Madagascar, it can go from 1 year to 99 years. It is one of the criticized measures taken by the government. Actually, local communities are deeply offended by the fact that sometimes it is their lands that are taken illegally.

\section{Literature Review}

\subsection{FDI Basic Theories}

In order to give answers to the question if Chinese investment a threat or opportunity, it is important to give a short reminder of some basic theories about FDI. In which case FDI is considered as a key to maximize benefits for a country?

Neoclassical paradigm authors such as Patrick Julliard and Dominique Car- 
reau introduced FDI as Foreign Direct Investment is a form of international capital flows. It may play an important role in the general allocation of world capital across countries. It is often pictured, together with other forms of capital flows, as shifting capital from rich, capital-abundant economies to poor, capital-scarce economies, so as to close the gap between the rates of return to capital and enhance the efficiency of the worldwide stock of capital. This is the neoclassical paradigm. This general portrayal of international capital flows may indeed pertain to FDI flows from developed countries to developing countries. The latter are almost all net recipients of FDI. Even in this case, multinational FDI investors bring to the host developing countries not only scarce capital but also superior technologies and new industries.

Therefore, there are many advantages to draw from foreign investment such as the transfer of capital from rich to poor countries that includes the establishment of multinationals, technology transfer and access to global markets.

In national and international accounting standards, FDI is defined as involving an equity stake of $10 \%$ or more. In general, FDI itself has three components: equity capital, intra-firm loans, and reinvestment of retained earnings. Because different countries have different recording practices relating to these three components, some measurement problems arise. Not all countries follow the $10 \%$ mark for the definition of FDI. The goal is to maximize benefits and minimize costs but the human capital and the development business in the host country must be improved. FDI should enhance capital formation.

\subsection{FDI's Legal Basis}

Countries are cooperating with each other in designing pro-FDI bilateral policies: The number of bilateral investment treaties (BITs) and double taxation treaties (DTTs) reached 2392 and 2559 respectively, in 2004, with developing countries concluding more such treaties with other developing countries.

The foreign investment is set by contract on investment (Parra, 1996) or contract or decision on funding or establishing, in accordance with law. Regulation of foreign investment at the international level is scarce. What exists for the most part is regulation of state behavior towards foreign investment. Hundreds of bilateral and multilateral treaties attempt to regulate that behavior, either exclusively or in combination with other matters, typically trade relations.

The provisions of these treaties apply equally to the treatment of investment by nationals of either party in the territory of the other party or parties (Shihata, 1993). However, they are mostly applied, and their standard forms are drafted by developed country parties with the intention to apply, to investment by nationals of the latter countries in developing countries. Several attempts by the OECD, largely a developed countries' organization, to reach agreement among its members on a convention on the treatment of foreign investments have not succeeded. A major developed country withdrew from the latest exercise on the basis that it constituted an encroachment on its sovereignty. 


\section{Methodology}

This study is based on descriptive method toward the quantitative designs carried out of questionnaire of data collection such as an online survey. Those questionnaires came up from local citizens who were seeking answers to the social problems caused by the growing presence of China's investors. My goal was to find, at the first time, the underlying motives of Chinese's investors behavior by asking first how do citizens feel about it. It is also based on some methods that allow giving more explanation of the strong presence of Chinese people and its effects on local communities in Madagascar. A collection of baseline data was the first task before doing an analysis of impacts of trade between China and Madagascar. The last step was the information and the policy analysis before drafting the report.

\section{Analysis}

To reach their goals, the Malagasy government has decided, even during many period of crisis, to push forward with challenging reforms. During those economic difficult times, Madagascar was at a disadvantage to compete for large global investment or to attract major investors. The reforms were set to reach two specific goals:

Setting incentive Policy

Adopting attractive laws

As far as incentive Policy is concerned, here are some examples of taken measures since 2003. At that time, the government chose the Poverty Reduction Strategy Paper (PRSP). They set some programs to achieve the objectives of strategic goal (Maunganidze, 2009) which is "encourage and promote economic growth through an expanded social base to demonstrate the importance of foreign direct investment in the development and revitalization of the private sector". The main impact of these measures will be, among other things, the reduction of the processing time records and the promotion of partnerships. To this end, the policy of promoting FDI has set the following objectives:

1) to make Madagascar the most preferred destination for investment in Sub-Saharan Africa and the Indian Ocean region;

2) to have economic growth in double figures;

3) to broaden the tax base in the medium and long term;

4) to promote foreign investment in sectors where value added, job creation, integration and multiplier effects in other sectors will be maximized.

Needless to say, that this kind of program can help at reaching the most important goal which is attracting investment. However, it is necessary to set some legislative provisions that can protect the hosting state. It aims at setting up a balance between the cooperating countries. Sometimes, some developing countries introduce some laws and regulations intended to protect some natural resources especially in the energy field against "foreign intruders".

Moreover, there are many laws that were adopted to set an attractive climate. 
First, investment in Madagascar is governed by several laws including Act No. 96-015 of September 13, 1996, which sets out the general guarantee offered to investors as well as Act2007-036 of January 14, 2008. To secure investor input and confidence, Madagascar joined the Multilateral Investment Guarantee Agency (MIGA/OGD) in order to protect investors against non-commercial risks. Madagascar is also a signatory to the Agreement establishing the Agency for Trade Insurance in Africa known as the African Trade Insurance Agency (ACA/ATI) to cover such policy risks affecting trade and financial transactions.

\section{Conclusion}

This paper aims at demonstrating the developmental effect of China's engagements in Madagascar. In fact, Madagascar is one of the poorest countries in the world (Labatut \& Raharinarivonirina, 1969) and it consistently ranks towards the bottom of the Human Development Index. In 2012, it was classified 151 out of 187 countries. Approximately $70 \%$ to $80 \%$ of the population lives in rural areas under subsistence conditions on an average Gross National Income per capita of US $\$ 950$. Madagascar is also one of those countries that have recognized after many years of independence that traditional development aid has not produced widespread poverty reduction across the continent and the introduction of new development partners in Africa has resulted in a process of self-reflection among the established donor community. Moreover, since the country's economy is dependent on donor funding, the call of foreign investments was compulsory.

My conclusion after this study is that China's presence in Madagascar can be a good opportunity that can be exploited to the benefit by the Malagasy government. In other words, it depends on how the host state manages it. Even there are some negative aspects that exist, China's investment in Madagascar is conducive to Malagasy development prospects for three reasons.

- China offers to Malagasy's government an alternative to the neo-liberal prescriptions of traditional investors, such as American and French who always condition their aid on democratic governance indicators.

- China's growing presence, somehow, affects Malagasy's daily lives by providing not only cheap goods that Malagasy's people can afford but also many useful infrastructures such as school, hospital, roads.

- China offers opportunities to Malagasy to improve their skills and learn from their ability to master new technologies.

The study of the case of the growing presence of China in Madagascar has taught me to have another vision of the situation. Even participants in this paper show negatives impact of tensions between the host State and civil society, I am convinced that there is much more to see than the self-perpetuating tendencies of negative stereotypes about this situation. Moreover, the propagation of negative thoughts about the activities of the Chinese investment in Madagascar does not let people to have a real appreciation of investor's goals in the country. The 
confidence between China's investors and civil society must be restored in order to alleviate the pressure and the stress between them.

There are somehow, many ways to restore peace and mutual understating between the two parties. First, it is necessary to Malagasy's people do develop their understanding of the frames of mind that promote conflict against Chinese investors. It will help local citizens to run away from their uncertainty about their safety and to believe again in social justice. Moreover, the other party should change their belief that they are superior to Malagasy's people. Anyway, it is useful to remind that there are important limitations to this research. The first one is the access. This study depends on the access to the companies or documents that are linked to those but unfortunately it is very difficult since many activities are kept secret. Beyond that, the recentness of the phenomenon (China's investment in Madagascar) prevents any researcher to have an ability to acquire critical data for a more and complete study in the future.

\section{Conflicts of Interest}

The authors declare no conflicts of interest regarding the publication of this paper.

\section{References}

Bardonnet, D. (1964). Asian Minorities in Madagascar (135 p). Extract from the French Directory of International Law.

Carreau \& Julliard (2013). International Economic Law. In Revue française d'études politiques africaines (5th ed., No. 26, 103 p). Paris: Dalloz. (In French)

Donque, G. (1968). Les Problèmes fondamentaux de l'urbanisme tananarivien. Revue de géographie, 13, 7-56.

Labatut, F., \& Raharinarivonirina (1969). Madagascar Historical Study (pp. 170-172). Paris: Editions Fernand Nathan. (In French)

LMS SLAWECKI (1964). The Origin and Growth of the Chinese Community in Madagascar. Bulletin de Madagascar, 276, 45-57. (In French)

Parra, A. (1996). The Scope of New Investment Laws and International Instruments. In R. Pritchard (Ed.), Economic Development, Foreign Investment and the Law (pp. 27-48). Location: Transnational corporations.

Shihata, I. (1993). Legal Treatment of Foreign Investment: The World Bank Guidelines (3rd ed., 155-216). Berlin: Springer.

Maunganidze, O. (2009). Madagascar: Anatomy of a Recurrent Crisis (Situation Report, pp. 1-11). Washington, DC: Institute for Security Studies.

PELLERIN (2011). The New Essor. UNDP and UNICEF Hired Frontier Advisory, a South African Advisory Firm Specialising in Asian-African Business Relationships.

\section{Reports}

Afrobarometer (2009). Madagascans and Democracy: Principles, Practices, and Participation. Afrobarometer Briefing Paper 64.

INSTATT's Report (2012). The National Statistics Institut Is a State Institut Which Establishes and Collect Statistics of All Kinds and Sources. It Carries Out and Produces Any 
Statitics about National Economic Aspects in Madagascar.

EDBM (2013) EDBM or Economic Development Board of Madagascar Is an Investment Promotion Agency in Madagascar Which Role Is to Set Objectives to Strengthen the Competitiveness of the Malagasy Private Sector. Colonial Statistics Service.

Doing Business Report (2020). 